\title{
ANTIBACTERIAL ACTIVITY OF CHITOSAN AND ITS OLIGOMERS ON SOME PATHOGENIC BACTERIA ISOLATED FROM SOME MILK PRODUCTS
}

\author{
MANAL M. AMIN and WALAA M.A. EL-SHERIF \\ Animal Health Research Institute, Agriculture Research Center (ARC), Food Hygiene, Assiut Regional Lab., Egypt.
}

Received: 5 September 2018; Accepted: 28 October 2018

\begin{abstract}
Chitosan and its oligomers $\mathrm{N}$-acetyl chitooligosaccharides and chito-oligosaccharides prepared by deacetylation and chemical hydrolysis, respectively and have a broad antimicrobial spectrum to Gram-positive (Staph.aureus and List. monocytogenes) bacteria and Gram-negative (Sal.typhimurium). Staph.aureus, List. monocytogenes and Sal. typhimurium were isolated in lower percentages $(23.3,0$ and $6.67 \%$, respectively) from talaga cheese, followed by zabadi-baladi and kariesh cheese. This study focused on antimicrobial activity of chitosan and its oligomers by inoculation it and the isolated bacteria in yoghurt. $1 \%$ of chitosan completely inhibited the Staph.aureus, List. monocytogenes at $5^{\text {th }}$ and $3^{\text {rd }}$ day, respectively and Chitosan exhibited a bacteriostatic effect on Sal. typhimurium. while $0.1 \%$ of $\mathrm{N}$-acetyl chitooligosaccharides and chito-oligosaccharides had reduced the count of List. monocytogenes and bactericidal effect on Staph.aureus and Sal. typhimurium. The antimicrobial properties of chitosan and its oligomers also, the perception of palatability to consumers toward it were discussed.
\end{abstract}

Key words: Chitosan, Zabadi baladi, Cheese, Antibacterial, Oligomers.

\section{INTRODUCTION}

Chitosan is nontoxic, a natural polymer, found in the exoskeletons of crustaceans (Rinaudo, 2006). It's found commercially in the waste products of the marine food processing industry (Limam et al., 2011). Recent studies have focused on conversion of chitosan to oligosaccharides (termed chitooligosaccharides, COS)—because the latter are not only readily soluble in water due to their shorter chain lengths, and free amino groups in Dglucosamine units, but also easily absorbed through the intestine, quickly getting into the blood flow (Kim and Rajapakse, 2005).

Chitosan and its oligomers are known for its various biological properties such as antioxidant, anti-inflammatory, cholesterol lowering, immunity enhancing, antitumor, neuroprotective, antimicrobial and antifungal which makes chitosan and its oligomers very useful polysaccharide for human health (Varun et al., 2017). Mechanism of inhibition of microbial cells by chitosan and its oligomers via its polycationic nature which electrostatically binds with the microbial surface and interferes with metabolism of bacteria or by blocking the transcription of RNA from DNA by adsorption on DNA after penetration to the

Corresponding author: WALAA M.A. EL-SHERIF

E-mail address: sch_qana@yahoo.com

Present address: Animal Health Research Institute, Assiut Lab., Egypt cell (Liu et al., 2001). Some authors have stated that chitosan generally showed stronger effects for Grampositive bacteria (e.g. Listeria monocytogenes, Bacillus megaterium, B. cereus, Staphylococcus aureus, Lactobacillus plantarum, L. brevis, $L$. bulgaris, etc.) than for Gram-negative bacteria (e.g. E. coli, Pseudomonas fluorescens, Salmonella typhimurium, Vibrio parahaemolyticus, etc.) (Goy et al., 2009). Conversely, it has been demonstrated that hydrophilicity in Gram-negative bacteria is significantly higher than in Gram-positive bacteria, making them most sensitive to chitosan (No et al., 2002).

Dairy products are most important products may be subjected to contamination by some pathogenic microorganisms through the unhygienic manipulation, transmission or during storage of these products. So, the chitosan is becoming more widely used in the food industry, particularly in the production of dairy products (Evdokimov et al., 2015). No et al. (2002) reported that the addition of chitosan to acidic foods enhances its effectiveness as natural preservative. Finally, Lee et al. (2004) concluded that a packaging material coated with a combination of nisin and chitosan improves significantly the microbial stability of milk.

This study aimed to elucidating the antimicrobial properties of chitosan and it's oligomers on different pathogenic microorganisms isolated from dairy product. 


\section{MATERIALS AND METHODS}

\section{I- Collection of samples:}

A total of 90 random samples of zabadi-baladi, Kareish cheese and Talaga cheese (30 of each) where collected from different markets and dairy shops in Assiut City, Egypt. The samples were collected in package as marketed to the consumer and sent to the laboratory in an insulated box with a minimum of delay to be examined.

\section{II- Isolation of some pathogenic bacteria:}

A- Isolation and identification of staph. aureus according to AOAC (2001) on paired barker agar, morphological examination and confirmatory tests done according to Bennett and Lancette (2001).

B- Isolation and identification of listeria monocytogenes: They isolated on Oxford agar plates after enriched in Listeria enrichment broth and identification was performed according to Hitchins et al. (2016).

C- Isolation and identification of Salmonella typhimurium according to Wallace et al. (2016): They pre-enriched on buffered peptone water then enriched on Rappaport-Vassiliadis (RV) broth and isolated on XLD agar. They identified according to FDA (2016).

III- Serological identification of Salmonellae: This part has been done in Serology Department in Animal Health Research Institute, El-Giza, Egypt. Serological identification of Salmonellae was carried out according to Kauffman - White scheme (Kauffman, 1974 and Popoff et al., 2004) for the determination of Somatic (O) and flagellar $(\mathrm{H})$ antigens using Salmonella antiserum (DENKA SEIKEN Co., Japan).

\section{IV- Preparation of N-actyl chito-} oligosaccharides and chito-oligosaccharides:-

$\mathrm{N}$-actyl chito-oligosaccharides (NAc-COS) were prepared by chemical hydrolysis of chitosan as follow: $1 \mathrm{~g}$ of chitin is hydrolyzed by $50 \mathrm{ml} 7 \mathrm{~N} \mathrm{HCl}$ at $70{ }^{\circ} \mathrm{C}$ during $3 \mathrm{~h}$. Chito-oligosaccharides (COS) were prepared by hydrolyze of $1 \mathrm{~g}$ of chitosan in $50 \mathrm{ml} 6 \mathrm{~N}$ $\mathrm{HCl}$ at $56{ }^{\circ} \mathrm{C}$ during $3 \mathrm{~h}$. (Chang et al., 2000 and Benhabiles et al., 2012).

\section{V- Bacterial suspension inoculation:}

The isolated strains were inoculated into Muller Hinton broth and incubated to the growth phase at $37^{\circ} \mathrm{C}$. The growth density was adjusted to match a MacFarland 0.5 standard $\left(10^{5} \mathrm{CFU} / \mathrm{ml}\right)$. (Ruparelia et al., 2008).

\section{VI- Antimicrobial properties of chitosan and} its oligomers (Benhabiles et al., 2012):

Raw milk was boiled for $10 \mathrm{~min}$. then suddenly cold and inoculated with $2 \%$ yoghurt culture at $45^{\circ} \mathrm{C}$. One $\mathrm{ml}$ of each strain suspension (which prepared as before) mixed with $100 \mathrm{ml}$ of prepared milk and divided into suitable sterile jars, chitosan, NAc-COS and COS were add at concentrations $1,0.1$ and $0.1 \%$ for each respectively, and another positive control jars without chitosan and oligomers, incubated at $40^{\circ} \mathrm{C}$ until curdling. Control jar (free from strains suspension, chitosan and oligomers as a negative control) was also stored. The jars were stored at refrigerator temperature $\left(5 \pm 2{ }^{\circ} \mathrm{C}\right)$. The inoculated jars were examined bacteriologically for the count of $S$. aureus using Baird-Parker media, Listeria monocytogenes using Oxford agar plates and Sal. typhimurium using XLD agar $\left(37^{\circ} \mathrm{C}\right.$ for $\left.24-48 \mathrm{~h}\right)$ after curdling (at time zero) and, every 2 days until the end of the experiment.

\section{VII- Sensory evaluation:}

Control yoghurt jars (free from the previous microorganisms but inoculated with chitosan and oligomers at concentrations of $1,0.1$ and $0.1 \%$, respectively) were prepared as previously mentioned and each was subjected to the previous treatments. Thirty consumers were selected in teams of different ages, sex (15 females and 15 males), and education to taste the trials. The perception of consumers toward samples with various conc. of chitosan was studied with respect to two different attributes (flavor and palatability) (Fernandes et al., 2008). The level of agreement was scored as strongly agree (SA), agree (A), disagree (D), and strongly disagree (SD) according to Nelson and Torut (1981). 


\section{RESULTS}

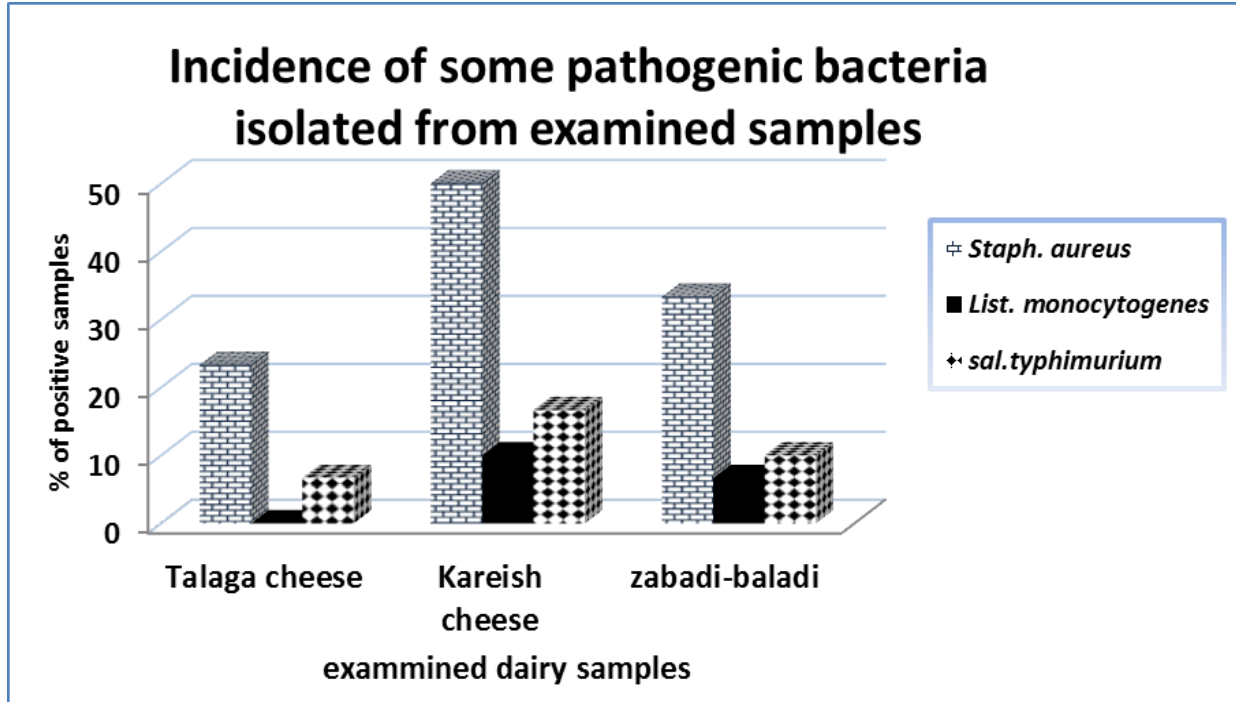

Fig. 1: Incidence of some pathogenic bacteria isolated from some diary samples.

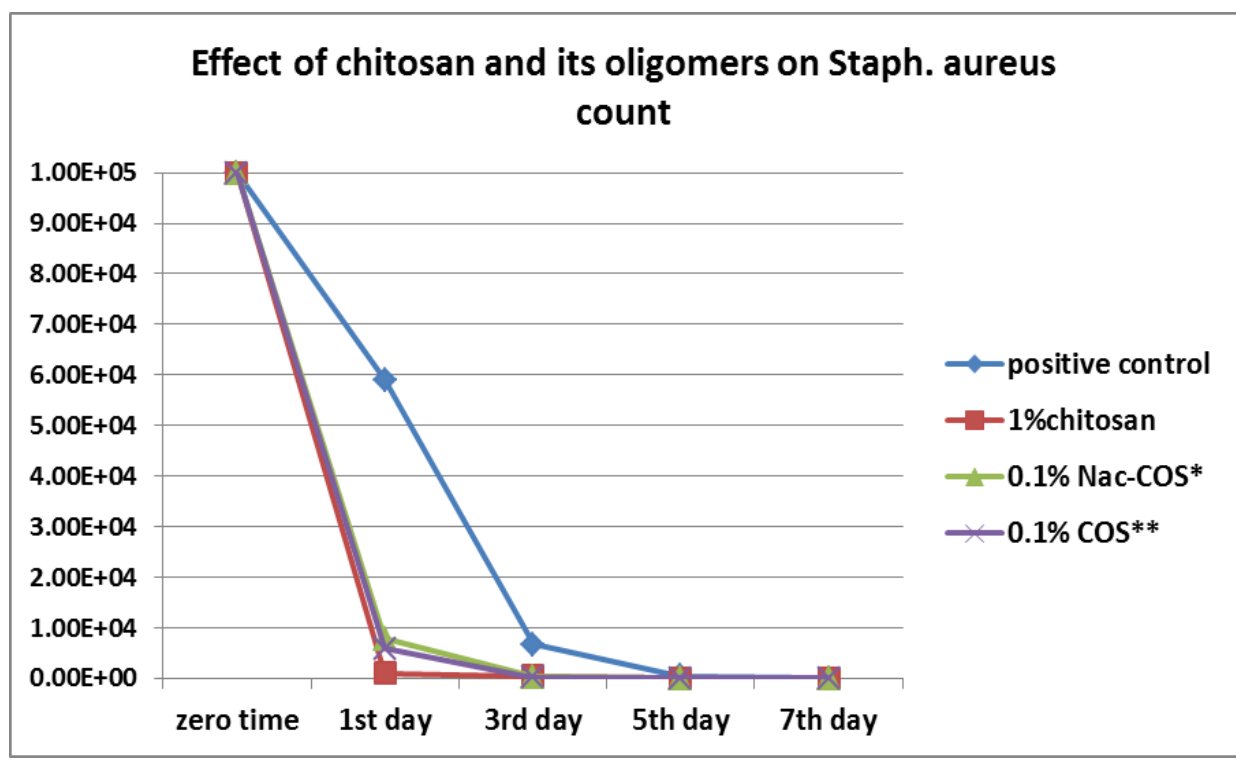

Fig. 2: Effect of chitosan and its oligomers on Staph.aureus inoculated in yogurt * N-actyl chito-oligosaccharides ** Chito-oligosaccharides

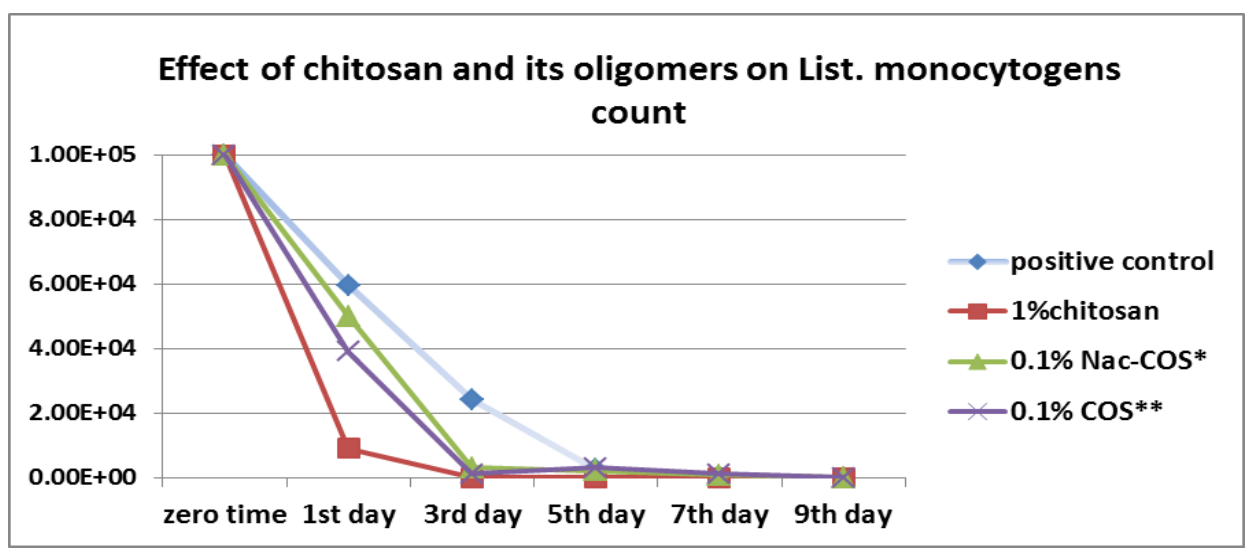

Fig. 3: Effect of chitosan and its oligomers on List. monocytogens inoculated in yogurt

* N-actyl chito-oligosaccharides ** Chito-oligosaccharides 


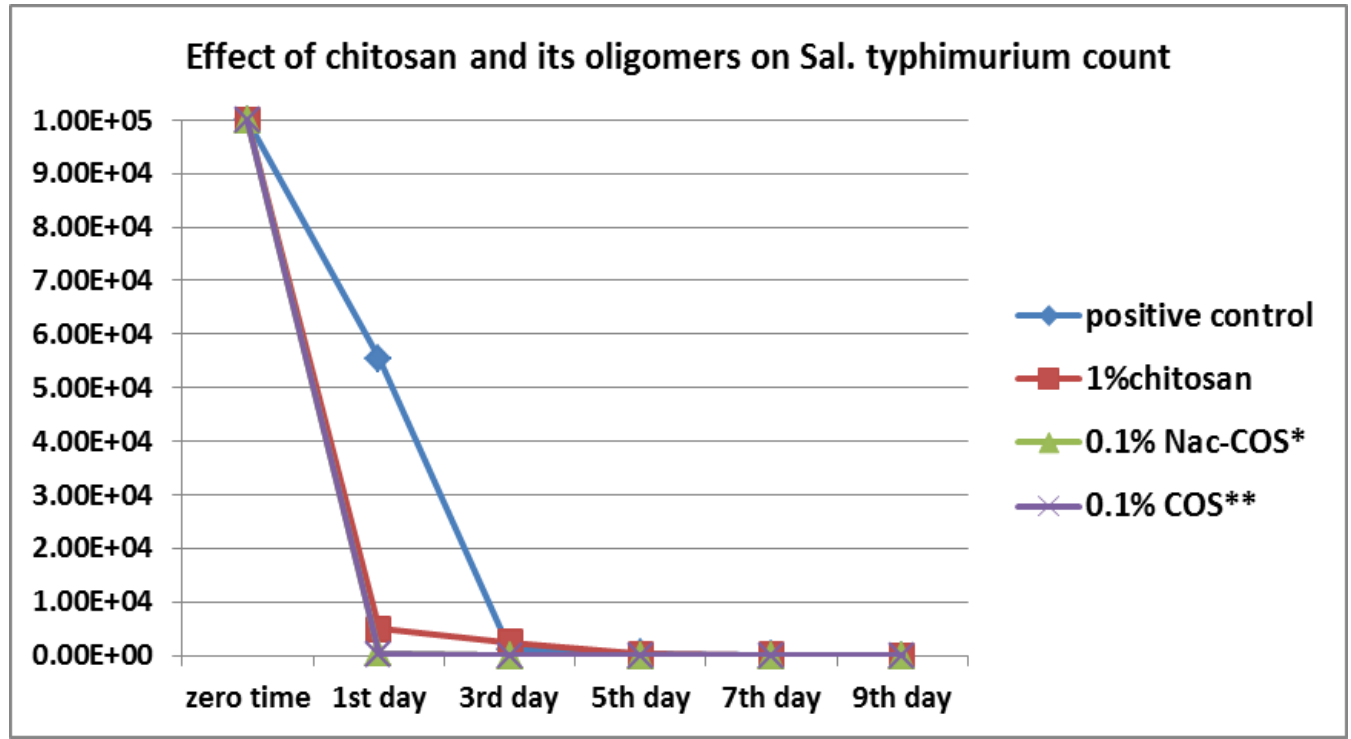

Fig. 4: Effect of chitosan and its oligomers on Sal. typhimurium inoculated in yogurt * N-actyl chito-oligosaccharides ** Chito-oligosaccharides

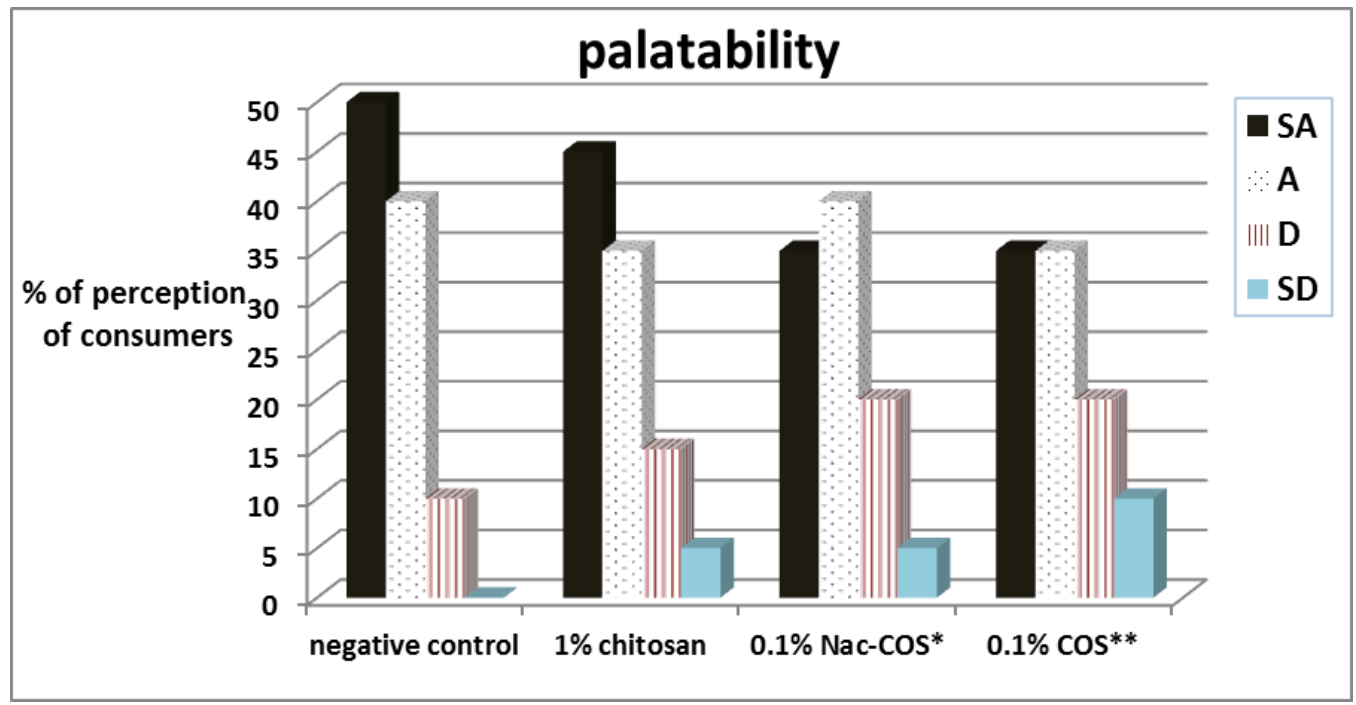

Fig. 5: Palatability of chitosan and its oligomers in yoghurt

* N-actyl chito-oligosaccharides ** Chito-oligosaccharides ** strongly agree (SA), agree (A), disagree (D), and strongly disagree (SD)

\section{DISCUSSION}

The aim of this study is to investigate some of dairy products for presence of some important pathogenic microorganisms that can make a risk for human and how control it by using natural materials as chitosan and its oligomers to help in controlling these pathogens from transmission specially in developing countries. So, in Fig. (1) clarified that Staph. aureus, List. monocytogenes and Sal. typhimurium could be isolated from Talaga cheese in percentages of 23.3, 0 and $6.67 \%$ respectively. While, from Kariesh cheese 50, 10 and $16.67 \%$ and from Yoghurt 33.3, 6.67 and $10 \%$ respectively. These results is lower than that obtained by Vitas et al. (2004) who isolated List.monocytogenes from soft cheese in $8.1 \%$,
Hussien et al. (2013) Stap.aureus in $85 \%$ and list.monocytogenes in $20 \%$ from Kariesh cheese. But, higher than results obtained by Bostan et al. (2006), Pelisser et al. (2009), and Ertas et al. (2010). Rahimi (2013) who reported Staph.aureus in $11.1 \%$ from soft cheese and $0 \%$ from yoghurt. Entry of foodborne pathogens via contaminated raw milk into dairy food processing plants can lead to persistence of these pathogens in biofilms, and subsequent contamination of processed milk products and exposure of consumers to pathogenic bacteria, pasteurization may not destroy all foodborne pathogens in milk, and inadequate or faulty pasteurization will not destroy all foodborne pathogens. Furthermore, pathogens such as List. monocytogenes can survive and thrive in postpasteurization processing environments, thus leading 
to recontamination of dairy products. These pathways pose a risk to the consumer from direct exposure to foodborne pathogens present in unpasteurized dairy products as well as dairy products that become recontaminated after pasteurization (Oliver et al., 2005).

As shown in Fig. $21 \%$ chitosan after $1^{\text {st }}$ day, $0.1 \%$ NAs-COS and $0.1 \%$ COS reduced the count of Staph. aureus until complete inhibition of the growth in yoghurt at $3^{\text {rd }}$ day in all trails. While, in positive control Staph.aureus could be detected in reduced count nearly until the $5^{\text {th }}$ day of experiment and that may be returned to increase the acidity of yoghurt and Staph. organisms are the most sensitive bacterial species to acidity (Bergdoll and Lee Wong, 2006). Similarly result recorded by, Fernandes et al. (2008) and Shanmugama et al. (2016) who showed the antibacterial effects of chitosan and chitooligomers against $S$. aureus and $E$. coli at $0.1 \%$ concentrations. Also, Amin (2014) studied that $1 \%$ chitosan could be complete the inhibition of Staph.aureus and enterotoxin type $\mathrm{C}$ at $6^{\text {th }}$ day in yoghurt trials. Goy et al. (2016) reported that chitooligomers have been inhibited many bacteria. A reduction on the growth colonies, where the chitosan concentration is confirmed to play important role in the antimicrobial activity. the chitosan is consistently more active against the Gram-positive Staph. aureus than Gramnegative bacteria. Antimicrobial activity of chitosan and its oligomers may be due to interference in the metabolism by binding to the surface of the bacteria or by blocking of transcription of DNA and RNA by binding to the DNA after penetration into cell. Chitooligomers showed antimicrobial action against pathogenic organisms and significantly inhibited Staph.aureus (Varun et al., 2017).

While, in Fig. 3 results clarified that $1 \%$ chitosan completely inhibited List.monocytogenes at $3^{\text {rd }}$ day but $0.1 \%$ of NAs-COS at $5^{\text {th }}$ day and COS reduce the count and could not be detected at $7^{\text {th }}$ day, reduction in List.monocytogenes counts with time progress in positive control trials. Similar results recorded by Jovanovi'c et al. (2016) and Hromiš et al. (2017) List.monocytogenes complete inhibited by $1 \%$ chitosan and less effected by its oligomers (NAs-COS and COS). No et al. (2002) studied the antibacterial activities of chitosans and chitosan oligomers with different molecular weights (Mws) were examined against Gram-negative and Gram-positive bacteria (Listeria monocytogenes). Chitosans showed higher antibacterial activities than chitosan oligomers and markedly inhibited growth of most bacteria tested although inhibitory effects differed with Mws of chitosan and the particular bacterium. Chitosan generally showed stronger bactericidal effects with Gram-positive bacteria than Gram-negative bacteria in the presence of $0.1 \%$ chitosan.
The mechanism of action of chitosan and its oligomers is differ from Gram positive and Gram negative bacteria so, the effect of them on Gram negative bacteria as Sal.typhimurium shown in Fig. 4 as results revealed that complete inhibition in growt of Sal.typhimurium at $3^{\text {rd }}$ day for $0.1 \%$ of NAs-COS and COS but just reduction in counts of it by $1 \%$ chitosan and thus in agreement with results recorded by Kong et al. (2010) and Hromiš et al. (2017). Also, Benhabiles et al. (2012) showed antimicrobial effect of chitooligomers against many pathogenic organism, i.e., Stap. aureus and Sal. typhimurium at $0.1 \%$ concentration of chitooligomers. The oligosaccharides NAc-COS and COS showed lower MIC values $(0.003 \%)$, compared to chitin and chitosan, for all Gram negative bacteria strains tested, indicating their stronger antimicrobial activity ( $\mathrm{Li}$ et al., 2010).

The microbiological target of protonated chitosan's action would be the cytoplasmic membrane of sensitive cells. Cellular damage can lead to the disruption of the cellular integrity of the membrane. The outer membrane of Gram-negative bacteria could act as a barrier and could be responsible for preventing chitosan from reaching the cytoplasmic membrane. Although the cytoplasmic membrane should be sensitive to chitosan, the outer membrane protects the cells (Coma et al., 2003). Also, Concerning the bacteria surface polarity, the outer membrane of Gram-negative bacteria consists essentially of lipopolysaccharides containing phosphate and pyrophosphate groups which render to the surface a density of negative charges superior to that observed for Gram-positive ones (membrane composed by peptidoglycan associated to polysaccharides and teichoic acids). This supports the evidence that the leakage of intracellular material observed by chitosan in Gram-negative is superior to that reported in Gram-positive bacteria (Chung and Chen, 2008).

The chitosan and its oligomers use in the dairy industry is very promising because it allows to profitably process milk protein and carbohydrate raw materials, excluding significant energy costs. The processed products have curative properties, which make them attractive for a consumer and, as a consequence, competitive at food market (Evdokimov et al., 2015). So, the perception of consumers toward samples subjected to various chitosan and oligomers conc. with respect to two different attributes (flavor and palatability) were regarded in Fig.5, $45 \%$ of consumers were strongly agree to addition of $1 \%$ chitosan while, only $35 \%$ of consumers for $0.1 \%$ for NAc-COS and COS. These results were in agreement with Amin (2014) but Duggan and Waghorne (2001) recorded that addition of chitosan to yoghurt shown dynamic rheological more better differences than those prepared without chitosan. Chitosan and its 
oligomers have little flavor effect when added to yoghurt at different concentrations.

In conclusion this study revealed the presence of antimicrobial activity of chitosan and its oligomers against most important food born pathogen. Chitooligomers would have advantages as new antimicrobial agents due to their higher activity and since they are also more readily soluble in water than the native polysaccharides (chitosan). N-acetyl chitooligosaccharides (NAc-COS) and chitooligosaccharides (COS) both have similar antibacterial activity. Further work is needed to better understand the mode of action of chitosan and its oligomers as antimicrobial agents. Also further study in dairy food plane to be applied in production, food packaging and field.

\section{REFERENCES}

Amin M. Manal (2014): The effectiveness of chitosan on the toxigenic Staph. aureus in yoghurt. Assiut vet. Med. J. 60 (140):169-175.

AOAC "Association of Official Analytical Chemists" (2001): International: Official Methods of Analysis method 2001.05. S.aureus count plate method for rapid detection of Staph. aureus in selected foods. J. AOAC Int. 84, 1431(2001).

Benhabiles, M.S.; Salah, R.; Lounici, H.; Drouiche, N.; Goosen, M.F.A. and Mameri, N. (2012): Antibacterial activity of chitin, chitosan and its oligomers prepared from shrimp shell waste. Food Hydrocolloids 29: 48-56.

Bennett, R.W. and Lancette, G.A. (2001): Staphylococcus aureus. In: FDA Bacteriological 1 Manual 8th Ed. Gaither sburg, MD, AOAC International:12.

Bergdoll, M.S. and Lee Wong, A.C. (2006): Staphylococcal intoxications. In: Foodborne Infections and Intoxications, (Eds) H.P. Reimann and D.O. Cliver, 523-562. Elsevier.

Bostan, K.; Cetin, O.; Buyukunal, S.K. and Ergun, O. (2006): The presence of Staphylococcus aureus and staphylococcal enterotoxins in ready-to-cook meatballs and whyte pyckled cheese. J. Fac. Vet. Med. Istanbul. Univ. 32: 31-39.

Chang, K.L.B.; Lee, J. and Fu, W.R. (2000): HPLC analysis of $\mathrm{N}$-acetyl-chito-oligosaccharides during the acid hydrolysis of chitin. Journal of Food and Drug Analysis, 8(2): 75-83.

Chung, Y.C. and Chen, C.Y. (2008): Antibacterial characteristics and activity of acid-soluble chitosan. Bioresour Technol. 99(8): 2806-14.

Coma, V.; Deschamps, A. and Martial-Gros, A. (2003): Bioactive Packaging Materials from Edible Chitosan Polymer-Antimicrobial Activity Assessment on Dairy-Related Contaminants. J. of Food Science 68 (9): 2788-2792.
Duggan, E. and Waghorne, E. (2001): effect of addition of chitosan on rheological properties of acidified milk gels. Proger Colloid Polym Sci. 118: 196-201

Ertas, N.; Gonulalan, Z.; Yildirim, Y. and Kum, E. (2010): Detection of Staphylococcus aureus enterotoxins in sheep cheese and dairy desserts by multiplex PCR technique. Int. J. Food Microbiol. 142:74-77.

Evdokimov, I.A.; Alieva, L.R.; Varlamov, V.P.; Kharitonov, V.D.; Butkevich, T.V. and Kurchenko, V.P. (2015): Usage of Chitosan In Dairy Products Production. Foods and Raw Materials. 3(2): 29-39.

FDA (2016): FDA Bactriological Analytical Manual, washington, DC: US Food and Drug Administration (https:// www.fda.gov/ Food/ FoodScienceResearch /LaboratoryMethods/ ucm070149.htm).

Fernandes, J.C.; Tavaria, F.K.; Soares, J.C.; Ramos, O.S.; Joao Monteiro, M.; Pintado, M.E. and Xavier Malcata F. (2008): Antimicrobial effects of chitosans and chitooligosaccharides, upon Staphylococcus aureus and Escherichia coli, in food model systems. Food Microbiol. 25(7): 922-8.

Goy, R.C.; Douglas, B.; Odilio B. and Assis, G. (2009): A Review of the Antimicrobial Activity of Chitosan. Polímeros: Ciência e Tecnologia, vol. 19(3): p. 241-247.

Goy, R.C.; Morais, S.T.B. and Assis, O.B.G. (2016): Evaluation of the antimicrobial activity of chitosan and its quaternized derivative on $\mathrm{E}$. coli and S. aureus growth. Revista Brasileira de Farmacognosia 26: 122-127.

Hitchins, A.D.; Jinneman, $K$. and Chen $Y$. (2016): Food and Drug Administration Bacteriological Analytical Manual Chapter 10 Detection and Enumeration of Listeria monocytogenes in foods. Available at: http://www.fda.gov/Food/FoodScienceRese arch/LaboratoryMethods/ucm071400.htm

Hromiš, N.; Lazić, V.; Bulut, S.; Popović, S.; Šuput, D.; Markov, S.; Džinić, N. and Tomović, $V$. (2017): Antimicrobial Activity of Composite Chitosan Biofilms With Beeswax And Caraway Essential Oil. Journal on Processing and Energy in Agriculture 21 (2):76-80

Hussien, M.F.; Amin, Manal M. and Sadek O.A. (2013): Comparison Between The Microbiological Quality Of Kareish Cheese Manufactured From Raw And Pasteurized Skimmed Milk Sold In Assiut City Markets. Assiut Vet. Med. J. 59 (138).

Jovanovi'c, G.D.; Klausb, S.A. and Nik'si', P. (2016): Antimicrobial activity of chitosan coatings and films against Listeria monocytogenes on black radish. Rev Argent Microbiol. 48(2): 128-136

Kauffman, G. (1974): Kauffman white scheme. J. Acta. Path. Microbiol. Sci., 61: 385. 
Kim, S.K. and Rajapakse, N. (2005): Enzymatic production and biological activities of chitosan oligosaccharides (COS): a review. Carbohydr. Polym. 62, 357-368.

Kong, M.; Chen, X.G.; Xing, K. and Park, H.J. (2010): Antimicrobial properties of chitosan and mode of action: A state of the art review. International Journal of Food Microbiology, 144, 51-63.

Lee, C.H.; Park, H.J. and Lee, D.S. (2004): Influence of antimicrobial packaging on kinetics of spoilage microbial growth in milk and orange juice. J. Food Eng. 65, 527-531.

Li, X.-F.; Feng, X.-Q. and Yang, S. (2010): A mechanism of antibacterial activity of chitosan against Gram-negative bacteria. Chinese Journal of Polymer Science, 31(13): 148-153.

Limam, Z.; Selmi, S.; Sadok, S. and El-abed, A. (2011): Extraction and characterization of chitin and chitosan from crustacean byproducts: biological and physicochemical properties. African Journal of Biotechnology, 10(4), 640-647.

Liu, X.; Yun, L.; Dong, Z.; Zhi, L. and Kang, D. (2001): Antibacterial action of chitosan and carboxymethylated chitosan. J. Appl. Polym. Sci., 79(7): 1324-1335.

Nelson, J.A. and Torut, G.M. (1981): Judging Dairy Products, $4^{\text {th }}$ ed., revised. Westport, CT: The AVC.

No, H.K.; Park, N.Y.; Lee, S.H. and Meyers, S.P. (2002): Antibacterial activity of chitosans and chitosan oligomers with different molecular weights. Int. J. Food Microbiol. 74, 65-72.

Oliver, S.P.; Jayarao, B.M. and Almeida, R.A. (2005): Foodborne pathogens in milk and the dairy farm environment: food safety and public health implications. Foodborne Pathog Dis. 2(2):115-29.

Pelisser, M.R.; Klein, C.S.; Ascoli, K.R.; Zotti, T.R. and Arisil, A.C.M. (2009): Occurrence of
Staphylococcus aureus and multiplex PCR detection of classic enterotoxin genes in cheese and meat products. Braz J. Microbiol. 40:145-148

Popoff, M.Y.; Bockemuhl, J. and Gheesling, L.L. (2004): Supplement 2002 (no. 46) to the Kauffmann-White scheme. Res. Microbiol.155: 568-70.

Rahimi, E. (2013): Enterotoxigenicity of Staphylococcus aureus isolated from traditional and commercial dairy products marketed in Iran. Brazilian Journal of Microbiology. 44(2): 393-399

Rinaudo, M. (2006): Chitin and chitosan: properties and applications. Prog. Polym. Sci. 31, 603632.

Ruparelia, J.P.; Chatterjee, A.K.; Duttagupta, S.P. and Mukherji, S. (2008): Strain specificity in antimicrobial activity of silver and copper nanoparticles. Acta Biomater. 4, 707-716.

Shanmugama, A.; Kathiresan, K. and Nayak, L. (2016): Preparation, characterization and antibacterial activity of chitosan and phosphorylated chitosan from cuttlebone of Sepia kobiensis (Hoyle, 1885). Biotechnol. Rep., 9: 25-30.

Varun, T.K.; Swaraj, S.; Natasha, J.; Jayaram C.; Sohini R.; Vijay B.; Tekulapally, V.B.; Mayank, G. and Narender, K. (2017): Extraction of chitosan and its oligomers from shrimp shell waste, their characterization and antimicrobial effect. Veterinary World J.10 (6): 170-175.

Vitas, I.A.; Aguado, V. and Garcia-Jalon, I. (2004): Occurrence of Listeria monocytogenes in fresh and processed food in Navarra (Spain). Int. J. Food Microbiol., 90 (2): 349-356.

Wallace, H.; Andrews; Hua Wang; Andrew Jacobson and Thomas Hammack (2016): Bacteriological Analytical Manual. Salmonella. August 2016 Version.

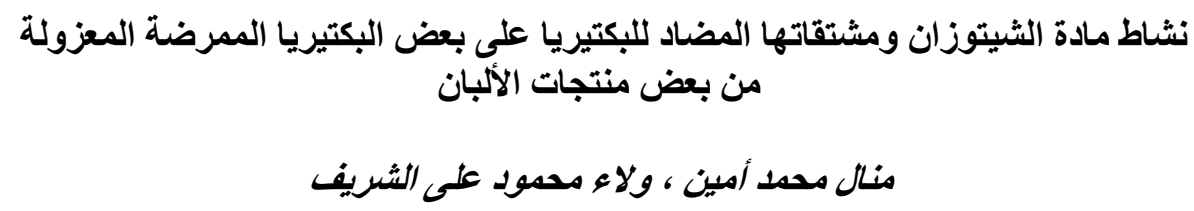

Email: sch_qana@yahoo.com Assiut University web-site: www.aun.edu.eg

ان الشيتوزان ومشتقاته لهم خصائص وظيفية عدة جذبت الكثير من العلماء لدر استها ودر استة تركيبها وتأثنير ها على البكتيريا وخاصة

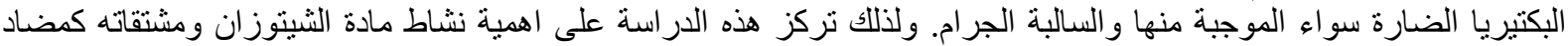

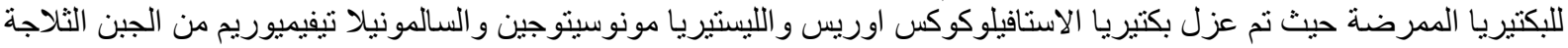

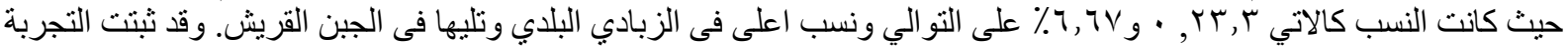

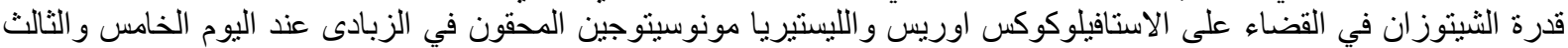

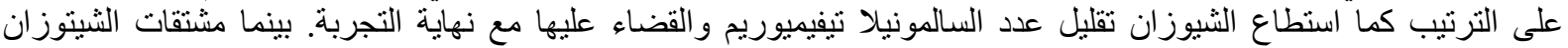

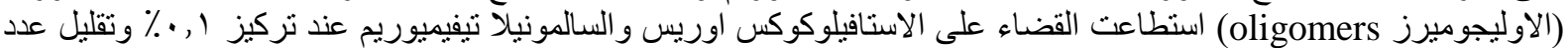

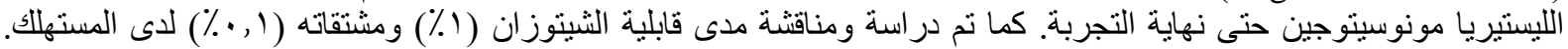

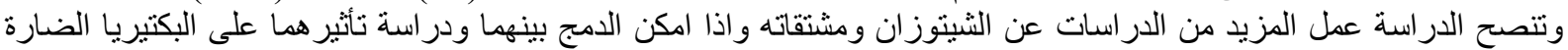

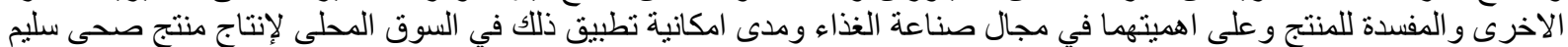

